\title{
On the suitability of Illius and Gordon's model for simulating the intake and digestibility of roughage diets by ruminants
}

\author{
I.V. Nsahlai ${ }^{1 \#}$ and J. Apaloo ${ }^{2}$ \\ ${ }^{1}$ Discipline of Animal and Poultry Science, School of Agricultural Sciences and Agribusiness, University of KwaZulu- \\ Natal, P/Bag X01, Scottsville, Pietermaritzburg 3209, South Africa \\ ${ }^{2}$ Department of Mathematics, Statistics and Computer Science, St. Francis Xavier University, P.O. Box 5000, \\ Antigonish, Nova Scotia, Canada B2G 2W5
}

\begin{abstract}
The aim of this study was to evaluate the suitability of Illius and Gordon's simulation model for predicting the digestibility and intake of tropical roughages by ruminants. Data from seven suitable empirical studies (i.e. studies that reported all requisite data needed to run the model) in which tropical roughages were fed to ruminants were used. These seven studies had 235 intake and 70 digestibility measurements on goats, sheep and cattle. The coefficient of variation (cv) of the observed digestibility was 13.8\%. A linear least square regression relationship between the observed (Y) and predicted (X) digestibility accounted for barely $37 \%$ of the variation for the entire data set $[Y=0.24($ s.e. $=0.056)+0.61(\mathrm{SE}=0.100)$ $\mathrm{X}]$ and for $53 \%$ of the variation when $5 \%$ of the observations were treated as outliers: $[\mathrm{Y}=0.17(\mathrm{SE}=0.047)+0.72(\mathrm{SE}=0.084) \mathrm{X}]$. For both equations the intercept and the slope were different from zero and unity, respectively. Although, a plot of residual digestibility showed no distinct pattern, this model should be used with extreme caution because of its inherent noise. The observed intake had a higher cv of $18.3 \%$. Regression relationships between the observed and predicted intakes accounted for barely $15 \%$ of the variation for the entire data set: $[\mathrm{Y}=30.1(\mathrm{SE}=7.39)+0.71(\mathrm{SE}=0.111) \mathrm{X}]$ and for $20 \%$ of the variation when $5 \%$ of the extreme values were treated as outliers: $[\mathrm{Y}=28.7(\mathrm{SE}=6.73)+0.75(\mathrm{SE}=0.101)$ $\mathrm{X}$. A residual plot showed that the model systematically underestimated the intake of roughages which elicited high intakes. The discussion was structured to identify, justify and propose pathways for enhancing the model.
\end{abstract}

Keywords: Ruminant, roughage intake, digestibility, model

${ }^{\#}$ Correspondence author. E-mail: nsahlaii@ukzn.ac.za

\section{Introduction}

Feed is the single most costly input into any livestock production enterprise and it is in the interest of livestock producers to use feed efficiently. Many attempts have been made at predicting intake in livestock raised on roughage diets using deterministic regression models. These models are state-specific and thus only valid under similar circumstances under which they have been developed. Some of these models rely entirely on animal characteristics (ARC, 1980) while others are based on feed properties such as degradability (Ørskov et al., 1988; Blumel \& Ørskov, 1993; Kibon \& Ørskov, 1993) or on urinary excretion products (Nsahlai et al., 2002). Since the relationship between roughage intake and degradability is a positive one, this only strengthens the view that roughage intake by ruminant animals is limited by rumen (gut) "fill". The fact that results obtained with these regression models are characterized by low reliability is understandable since these models do not take advantage of both the animal and plant factors that affect intake. However, the use of degradability as intake predictor is desirable because of the ease of implementation of the nylon bag procedure. However, there is a need to integrate in sacco feed properties with animal factors that affect intake in order to transcend situation-specific predictions. Furthermore, Robellin \& Geay (1984) showed that gut fill expressed per unit body weight increased to peak value between 200 and $250 \mathrm{~kg}$ of full body weight, and then decreased.

There is also a considerable body of evidence suggesting that animals at different physiological stages differ in their intake of roughage diets and in their response to supplementation. For instance, while lactating animals consume more feed (Hartnell \& Satter, 1979), an animal at late pregnancy may exhibit a low intake because the foetus grows rapidly and occupies part of the abdominal cavity. This agrees with Butterfield 
(1988) who established a maturity coefficient of 2.14 for the reticulo-rumen contents. On the contrary, both pregnant (Lindsay et al., 1982; Weston, 1988) and lactating (Nsahlai, 1991) animals respond markedly to protein supplementation by eating more in view of their high requirements for protein and energy to meet the needs of either the rapidly growing foetus or synthesis of milk constituents. There are thus justifiable reasons why intake prediction based on either of the above approaches alone can yield nothing other than situation-specific results. In an attempt to bridge this gap Nsahlai et al. (1996), using a multiplicative strategy, developed an empirical statistical model for predicting the intake of forage legume-supplemented roughage diets. This is a static model which would become too complicated if attempts are made to accommodate more than one livestock species.

A widely applicable approach for pursuing the goal of predicting the intake of roughage diets for ruminant species would be to use simulation modelling. This study, while remaining fairly simple, will take advantage of some previous generalisations proposed by Poppi et al. (1981a; b), Illius \& Gordon (1991) and Sauvant et al. (1996). The model of Illus \& Gordon (1991) was originally developed to provide insight into how body size influences the ability of the animal to obtain their energy requirement from poor quality feeds, and so bears the attractive feature of generalizing across ruminant livestock. The aim of this study is to test the suitability of Illius and Gordon's simulation model for predicting the digestibility and intake of tropical roughage based diets by ruminants.

\section{Materials and Methods}

The simulation model of Illius \& Gordon (1991) comprises 13 digesta pools in the rumen and six postruminal pools. Fluxes among pools are modelled by a system of ordinary differential equations. Ingesta was partitioned physically into long and short particles based on empirical data, chemically into cell content (CC) and cell wall (CW) based on neutral detergent extraction, and biologically into digestible CW (DNDF) and indigestible CW (INDF) based on both the in sacco degradability (Merhez \& Ørskov, 1977) and neutral detergent extraction (Van Soest et al., 1991). Once feed has been consumed, the cell content in the fine particle pool is subjected instantly to the digestion processes, while all other particles are retained in the rumen until the lag phase that precedes the onset of digestion has elapsed. The model assumes that the lag phase is inversely related to the soluble cell content and also recognises ruminal fill as a factor which limits roughage intake. Therefore, solid matter in the rumen, including dry matter (DM) in the lag phase, DM in the process of microbial digestion and microbial matter contributes to the level of fill. Maximum rumen DM load was determined by allometry as a function of body weight. Ingesta disappeared from the rumen at a rate determined by the fractional rate (FR) of degradation $\left(\mathrm{k}_{\mathrm{dig}}\right.$ or $\left.\mathrm{k}_{2}\right)$ which was determined in sacco, and the FRs of passage of particles $\left(k_{p}\right)$ through the rumen were computed separately for the short $\left(k_{3}, k_{5}\right)$ and the long particle $\left(\mathrm{k}_{5}, \mathrm{k}_{8}\right)$ pools. The model allows a maximum of eight meals per day. All computations were as described by Illius \& Gordon (1991) following the scheme of digesta flux depicted in Figure 1.

Data from seven suitable studies (i.e. studies that reported all requisite data needed to run the model) in which tropical roughages were fed to ruminants were used to evaluate the simulation model. The seven studies that qualified for the evaluation had 235 intake and 70 digestibility measurements obtained from studies using cattle, goats and sheep. All observations were used. In these studies animals were offered 1.15 to 1.20 of the ad libitum intake and orts were weighed before offering fresh feed (Table 1) during the digestibility and the intake phases. Small ruminants were housed in individual pens during the intake phase but were transferred to metabolism crates during the digestibility phase of the study. However, cattle were housed in tie-stalls during the entire duration of the study and faeces were immediately removed from concrete floors and placed in collection buckets until weighed. Details are given in each of these studies. Animals used for degradation studies in all but the study by Mpairwe (1998) were provided with a protein supplement (Table 1). 


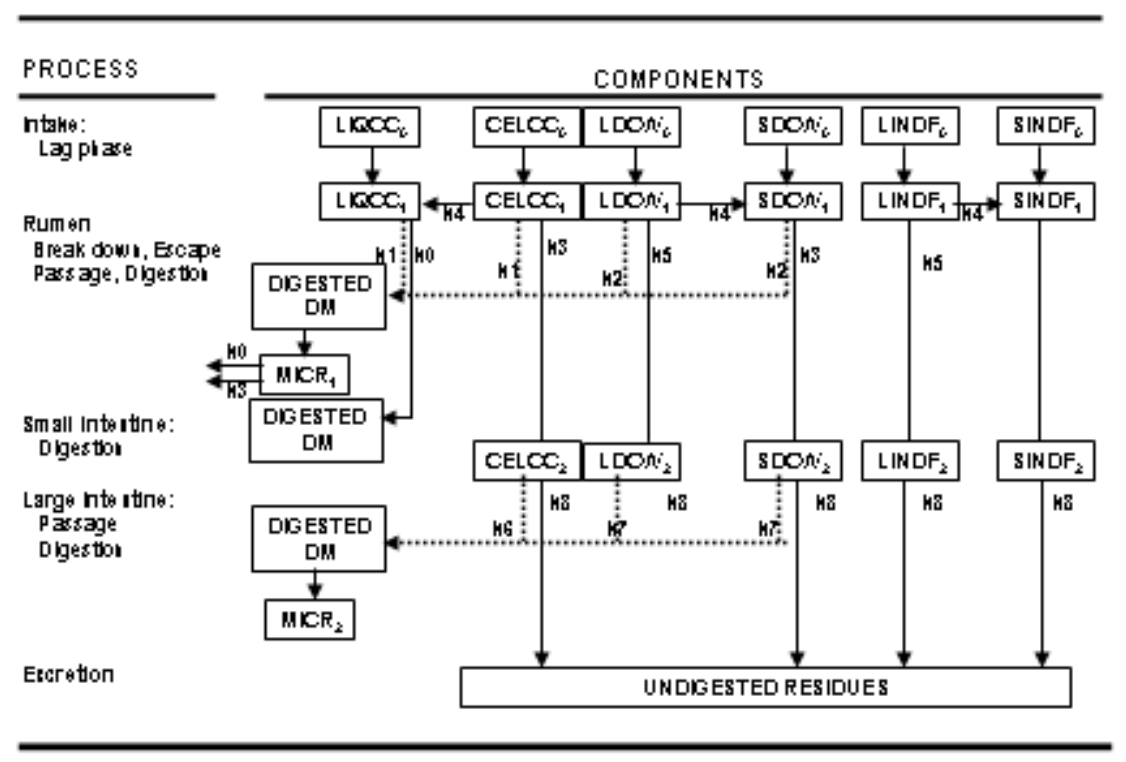

Figure 1 Flow diagram of the digesta flux among digesta pools based on the model of Illius \& Gordon (1991). Subscripts 0, 1 and 2 represent digesta in the lag phase, ruminal and hindgut pools, respectively. CELCC is the soluble cell content within the cell walls, LIQCC the free cell content, LDCW the long digestible cell wall, SDCW the short digestible cell wall, LINDF the long indigestible cell wall, and SINDF the short indigestible cell wall. $\mathrm{k} 0$ to $\mathrm{k} 8$ are the rates of flow among digesta pools. MICR1 and MICR2 represent microbial matter synthesized in the rumen and hindgut, respectively.

Table 1 Feeding programme during in sacco feed evaluation and during intake and digestibility experiments used in this study

\begin{tabular}{|c|c|c|c|c|c|c|c|}
\hline \multirow[b]{2}{*}{ Source $^{\#}$} & \multicolumn{3}{|c|}{ Supplement used during in sacco studies } & \multicolumn{4}{|c|}{$\begin{array}{l}\text { Feeding level and supplement (S) used during the } \\
\text { intake and digestibility studies }\end{array}$} \\
\hline & Animal & Type $(S)^{\dagger}$ & Kg DM/day & Animal & $\begin{array}{c}\text { Feeding } \\
\text { level }^{\dagger+}\end{array}$ & $\begin{array}{l}\text { Type } \\
\text { (S) }\end{array}$ & $\begin{array}{c}\mathrm{Kg} \\
\text { S/day }\end{array}$ \\
\hline 1 & Sheep & $\mathrm{CSC}$ & 2.5 & Sheep & Ad libitum & None & - \\
\hline 2 & Cattle & None & - & Cattle & Ad libitum & None & - \\
\hline 3 & Cattle & $\mathrm{CSC}$ & 1.0 & Cattle & Ad libitum & CSC & 1.0 \\
\hline 4 & Goats & Grass nuts & 0.2 & Goats & Ad libitum & None & - \\
\hline 5 & Cattle & $\mathrm{CSC}$ & $1.5-2.5$ & Cattle & Ad libitum & None & - \\
\hline 6 & Cattle & CSC: $\mathrm{WM}^{\$}$ & 3.0 & Cattle & Ad libitum & None & - \\
\hline 7 & Sheep & CSC & 0.2 & Sheep & Ad libitum & None & - \\
\hline
\end{tabular}

${ }^{\dagger} \mathrm{CSC}$ is cottonseed cake and WM is wheat middling; ${ }^{\dagger \dagger} \mathrm{Ad}$ libitum represents a feeding 1.15 to 1.2 times the daily intake. \#: 1 = Nsahlai et al., 1996a; 2 = Mpairewe, 1998; 3 = Shem et al., 1995; 4 = Kibon \& Ørskov, 1993; 5 = Nsahlai et al., 1996b; 6 = Umunna et al., 1995; 7 = Nsahlai et al., 1998a; ${ }^{\text {\$: }}$ 50:50 ratio of cottonseed cake and wheat middling.

These studies covered a wide range of live weights and feeds of which the attributes are summarized in Tables 2a, b \& c. Live weight and feed attributes constituted input variables into the model. The system of differential equations constituting the model was solved numerically using the ODE23 routine in Matlab 6.1. The simulation model checks for the onset of digestibility and/or intake on an hourly basis. Intake and digestibility are allowed to attain steady state over $120 \mathrm{~h}$, and thereafter solutions for intake and digestibility 
are generated for the diet. This procedure is then repeated for each diet. The intake and digestibility values predicted by the simulation model and the corresponding values observed from the empirical studies were then compared using linear regression procedure and the general linear model procedure in SAS (2002/2003). Residuals (observed minus predicted values) were analyzed to determine which factors among feed type (leguminous forages, browses, mixed diets of forage legumes and cereal straws, cereal straws and hays) were responsible for the most deviation. The effects of animal species were not estimable, so the covariate effect of live weight was used to discern if the size of the animals affected the residuals. In addition the crude protein (CP) content of the diet was introduced as a covariate to determine if the effect of feed type was partly due to the nitrogen $(\mathrm{N})$ content.

\section{Results}

The regression relationship between the observed $(\mathrm{Y})$ and the predicted $(\mathrm{X})$ DM digestibilities $(\mathrm{g} / \mathrm{g})$ was positive, as seen from the equation: $\mathrm{Y}=0.23(\mathrm{SE}=0.056)+0.62(\mathrm{SE}=0.100) \mathrm{X}(\mathrm{n}=70, \mathrm{RSD}=0.08$, $\left.\mathrm{R}^{2}=0.37\right)$. The intercept and the slope were significantly different $(\mathrm{P}<0.001)$ from zero and unity, respectively. This relationship is depicted in Figure 2A. Residual DM digestibility values were plotted against the observed to assess the overall goodness of the predictions (Figure 2B). With the exception of two very extreme values the residual plots showed no obvious pattern. It was also noticed that the model tended to predict values that were at least $20 \%$ lower than the observed for some really poor quality roughages (wheat straw, barley straw), and values that were at least 20\% higher than the observed for legume forages such as Leucaena leucocephala, cowpea hay, lablab hay and Desmodium intortum hay. The overall cv for digestibilities used in this validation was $13.8 \%$. About $2 \%, 20 \%$ and $46 \%$ of the predicted digestibility values were 2, 1.5, and 1 times the residual standard deviation (SD) higher or lower than the observed values, respectively. When $5 \%$ of the outlying observations were eliminated, the regression of the observed $(\mathrm{Y})$ against the predicted $(\mathrm{X})$ digestibility gave the equation: $\mathrm{Y}=0.17(\mathrm{SE}=0.047)+0.72(\mathrm{SE}=0.084) \mathrm{X}$, $\left(n=67 ; \mathrm{RSD}=0.066 ; \mathrm{R}^{2}=0.53\right)$. The intercept and the slope were also significantly different $(\mathrm{P}<0.01)$ from zero and unity, respectively.

The residual digestibility varied with the feed types in the order $-0.06,0.09,0.07$ and 0.02 for forage legumes, browses, mixed diets and other roughages, respectively. The residual digestibility decreased with increasing dietary CP content $(-0.0003 / \mathrm{g} C P ; \mathrm{P}=0.072)$, but was not affected by live weight.

The regression relationship between the observed $(\mathrm{Y})$ and the predicted $(\mathrm{X}) \mathrm{DM}$ intake $\left(\mathrm{g} / \mathrm{g} \mathrm{w}^{0.73}\right)$ is positive, and is represented by the equation: $\mathrm{Y}=30.1(\mathrm{SE}=7.39)+0.71(\mathrm{SE}=0.111) \mathrm{X}(\mathrm{n}=234$, $\mathrm{RSD}=$ $\left.14.62, \mathrm{R}^{2}=0.15\right)$. The intercept and the slope are significantly different $(\mathrm{P}<0.001)$ from zero and unity, respectively. This relationship is depicted in Figure 2C. Residual DM digestibility values were plotted against the observed to assess the overall goodness of the predictions from the simulation (Figure 2D). It can be observed from the plot that the residual intakes increased systematically with increasing intake. Furthermore, the overall cv for the intakes of the feeds used in the field experiments that were used in the model validation is $8.3 \%$. It was observed that $22 \%, 41 \%, 66 \%$ and $86 \%$ of the predicted intakes were $1,2,3$ and 4 times the SD higher or lower than the observed, respectively. Upon elimination of 5\% of the extreme observations, the refitted equation is: $\mathrm{Y}=28.7(\mathrm{SE}=6.73)+0.75(\mathrm{SE}=0.101) \mathrm{X}(\mathrm{n}=223, \mathrm{RSD}=12.66$, $\left.\mathrm{R}^{2}=0.20\right)$. Both the intercept and the slope differ $(\mathrm{P}<0.05)$ from zero and unity, respectively, with the relationship accounting for just $20 \%$ of the variation.

The residual intake decreased $(\mathrm{P}<0.01)$ by $0.036 \mathrm{~g} / \mathrm{kg}$ body weight and by $0.131 \mathrm{~g} / \mathrm{g} \mathrm{CP}$ content. Residuals were generally highest for mixed diets and other roughage diets (cereal straws and grass hays) and as such were in the order of $-3.12,5.37,25.92$ and 10.67 for forage legumes, browses, mixed diets and other roughages, respectively. 
Table 2a Data for testing the model (digestible cell wall (DCW), indigestible neutral detergent fibre (INDF), rate of digestion ( $\mathrm{k}_{\text {dig }}$ ), organic matter (OM) and the observed (Obs) vs. predicted (Pred) intake ( $/ \mathrm{kg}$ weight ${ }^{0.73}$ ) and digestibility coefficient (DMD, g/g). CP - crude protein content of the diet (g/kg)

\begin{tabular}{|c|c|c|c|c|c|c|c|c|c|c|c|c|c|}
\hline \multirow[b]{2}{*}{ Source ${ }^{\#}$} & \multirow[b]{2}{*}{ Feed type } & \multicolumn{2}{|c|}{ Animal attributes } & \multicolumn{6}{|c|}{ Feed attributes } & \multicolumn{4}{|c|}{$\begin{array}{l}\text { Observed and predicted intake and } \\
\text { digestibility }\end{array}$} \\
\hline & & Type & $\begin{array}{l}\text { Wt range } \\
(\mathrm{kg})\end{array}$ & $\begin{array}{l}\text { Cellcc } \\
(\mathrm{g} / \mathrm{g})\end{array}$ & $\begin{array}{l}\text { DCW } \\
(g / g)\end{array}$ & $\begin{array}{l}\text { INDF } \\
(\mathrm{g} / \mathrm{g})\end{array}$ & $\begin{array}{l}\mathrm{k}_{\mathrm{dig}} \\
(/ \mathrm{h}) \\
\end{array}$ & $\begin{array}{l}\text { OM } \\
(g / g)\end{array}$ & $\begin{array}{l}\mathrm{CP} \\
(\mathrm{g} / \mathrm{kg}) \\
\end{array}$ & $\begin{array}{l}\text { Obs } \\
\text { DMD }\end{array}$ & $\begin{array}{l}\text { Pred } \\
\text { DMD } \\
\end{array}$ & $\begin{array}{l}\text { Obs } \\
\text { intake }\end{array}$ & $\begin{array}{l}\text { Pred } \\
\text { intake }\end{array}$ \\
\hline 1 & Chickpea straw & sheep & 25.6 & 0.415 & 0.229 & 0.356 & 0.051 & 0.915 & 87.5 & 0.56 & 0.56 & 56.6 & 58.9 \\
\hline 1 & Cowpea hay (regrowth) & sheep & 25.6 & 0.624 & 0.156 & 0.220 & 0.066 & 0.850 & 218.8 & 0.57 & 0.72 & 62.6 & 82.9 \\
\hline 1 & Cowpea hay (first cut) & sheep & 25.6 & 0.537 & 0.306 & 0.157 & 0.037 & 0.670 & 162.5 & 0.63 & 0.70 & 79.9 & 79.5 \\
\hline 1 & Desmodiun intortum (hay) & sheep & 25.6 & 0.522 & 0.431 & 0.047 & 0.010 & 0.884 & 212.5 & 0.52 & 0.61 & 66.5 & 70.8 \\
\hline 1 & Haricot bean straw & sheep & 25.6 & 0.339 & 0.317 & 0.344 & 0.048 & 0.906 & 62.5 & 0.60 & 0.54 & 55.2 & 55.5 \\
\hline 1 & Lablab hay (first cut) & sheep & 25.6 & 0.580 & 0.251 & 0.169 & 0.057 & 0.913 & 137.5 & 0.68 & 0.74 & 73.4 & 87.1 \\
\hline 1 & Lablab hay & sheep & 25.6 & 0.652 & 0.046 & 0.302 & 0.064 & 0.869 & 193.8 & 0.53 & 0.66 & 61.9 & 73.6 \\
\hline 1 & Leucaena leucocephala & sheep & 25.6 & 0.623 & 0.083 & 0.294 & 0.017 & 0.905 & 250.0 & 0.40 & 0.63 & 71.0 & 70.0 \\
\hline 1 & Barley straw & sheep & 25.6 & 0.231 & 0.391 & 0.378 & 0.014 & 0.897 & 37.5 & 0.48 & 0.35 & 49.7 & 45.8 \\
\hline 1 & Cynodon hay & sheep & 25.6 & 0.300 & 0.234 & 0.466 & 0.019 & 0.873 & 62.5 & 0.49 & 0.38 & 69.8 & 47.2 \\
\hline 1 & Debre Zeit native hay & sheep & 25.6 & 0.271 & 0.325 & 0.404 & 0.016 & 0.902 & 50.0 & 0.47 & 0.38 & 62.6 & 47.0 \\
\hline 1 & Maize cowpea intercropped roughage & sheep & 25.6 & 0.449 & 0.279 & 0.272 & 0.039 & 0.894 & 118.8 & 0.59 & 0.60 & 64.3 & 63.2 \\
\hline 1 & Maize lablab intercropped roughage & sheep & 25.6 & 0.429 & 0.336 & 0.235 & 0.026 & 0.914 & 75.0 & 0.62 & 0.58 & 69.8 & 61.5 \\
\hline 1 & Maize stover & sheep & 25.6 & 0.280 & 0.603 & 0.117 & 0.010 & 0.892 & 37.5 & 0.49 & 0.43 & 48.0 & 51.0 \\
\hline 1 & Oat hay & sheep & 25.6 & 0.364 & 0.285 & 0.351 & 0.029 & 0.906 & 50.0 & 0.55 & 0.50 & 62.4 & 53.5 \\
\hline 1 & Oat straw & sheep & 25.6 & 0.262 & 0.315 & 0.423 & 0.024 & 0.922 & 31.3 & 0.39 & 0.40 & 48.7 & 47.7 \\
\hline 1 & Oat/vetch intercropped roughage & sheep & 25.6 & 0.401 & 0.154 & 0.445 & 0.029 & 0.911 & 68.8 & 0.56 & 0.47 & 70.3 & 51.6 \\
\hline 1 & Sorghum stover & sheep & 25.6 & 0.303 & 0.497 & 0.200 & 0.012 & 0.874 & 56.3 & 0.47 & 0.44 & 54.5 & 51.1 \\
\hline 1 & Sululta native hay & sheep & 25.6 & 0.287 & 0.375 & 0.338 & 0.024 & 0.921 & 50.0 & 0.47 & 0.46 & 49.2 & 50.6 \\
\hline 1 & Teff straw & sheep & 25.6 & 0.207 & 0.650 & 0.143 & 0.008 & 0.898 & 50.0 & 0.44 & 0.34 & 41.8 & 46.6 \\
\hline 1 & Wheat straw & sheep & 25.6 & 0.276 & 0.311 & 0.413 & 0.045 & 0.895 & 31.3 & 0.39 & 0.47 & 42.0 & 50.9 \\
\hline 1 & Wheat/trifolium intercropped roughage & sheep & 25.6 & 0.330 & 0.170 & 0.500 & 0.026 & 0.848 & 68.8 & 0.57 & 0.40 & 66.0 & 48.0 \\
\hline
\end{tabular}

${ }^{\#} 1$ = Nsahlai et al., 1996a 
Table 2b Data for testing the model (digestible cell wall (DCW), indigestible neutral detergent fibre (INDF), rate of digestion ( $\mathrm{k}_{\mathrm{dig}}$ ), organic matter (OM) and the observed (Obs) vs. predicted (Pred) intake (g/kg weight ${ }^{0.73}$ ) and digestibility coefficient (DMD, g/g). CP - crude protein content of the diet (g/kg)

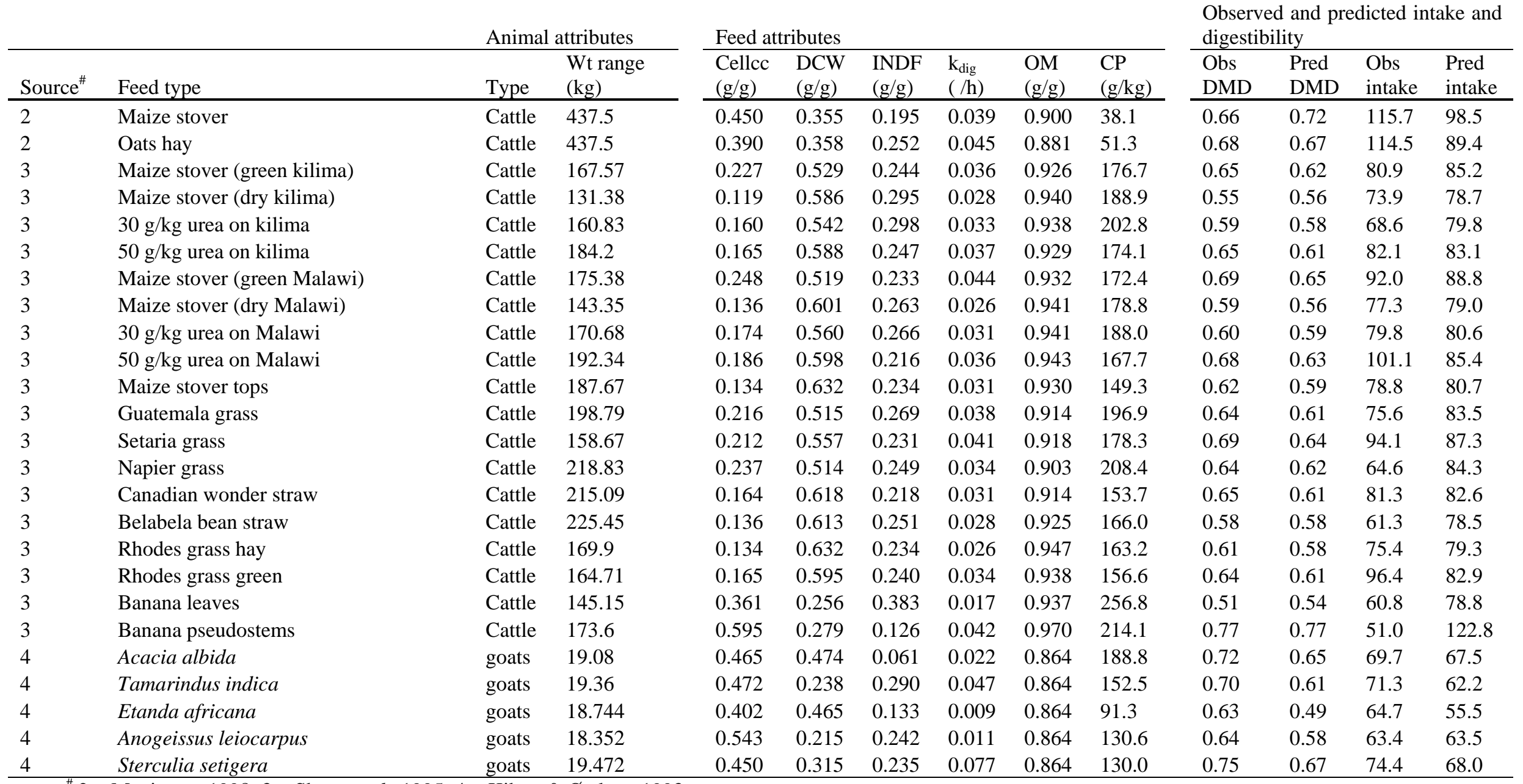

\# 2 = Mpairewe, 1998; 3 = Shem et al., 1995; 4 = Kibon \& Ørskov, 1993 
Table 2c Data for testing the model (digestible cell wall (DCW), indigestible neutral detergent fibre (INDF), rate of digestion ( $\mathrm{k}_{\text {dig }}$ ), organic matter (OM) and the observed (Obs) vs. predicted (Pred) intake (g/kg weight ${ }^{0.73}$ ) and digestibility coefficient (DMD, g/g). CP - crude protein content of the diet (g/kg)

\begin{tabular}{|c|c|c|c|c|c|c|c|c|c|c|c|c|c|}
\hline \multirow[b]{2}{*}{ Source ${ }^{\#}$} & \multirow[b]{2}{*}{ Feed type } & \multicolumn{2}{|c|}{ Animal attributes } & \multicolumn{6}{|c|}{ Feed attributes } & \multicolumn{4}{|c|}{$\begin{array}{l}\text { Observed and predicted intake and } \\
\text { digestibility }\end{array}$} \\
\hline & & Type & $\begin{array}{c}\text { Wt range } \\
(\mathrm{kg})\end{array}$ & $\begin{array}{l}\text { Cellcc } \\
(\mathrm{g} / \mathrm{g})\end{array}$ & $\begin{array}{l}\text { DCW } \\
(\mathrm{g} / \mathrm{g})\end{array}$ & $\begin{array}{l}\text { INDF } \\
(\mathrm{g} / \mathrm{g})\end{array}$ & $\begin{array}{l}\mathrm{k}_{\mathrm{dig}} \\
(/ \mathrm{h})\end{array}$ & $\begin{array}{l}\text { OM } \\
(\mathrm{g} / \mathrm{g})\end{array}$ & $\begin{array}{l}\text { CP } \\
\text { (g/kg) }\end{array}$ & $\begin{array}{l}\text { Obs } \\
\text { DMD }\end{array}$ & $\begin{array}{l}\text { Pred } \\
\text { DMD }\end{array}$ & $\begin{array}{c}\text { Obs } \\
\text { intake }\end{array}$ & $\begin{array}{l}\text { Pred } \\
\text { intake }\end{array}$ \\
\hline 5 & Barley straw & calf & $56-153$ & 0.239 & 0.381 & 0.380 & 0.019 & 0.910 & 38.1 & 0.76 & 0.43 & 73.4 & 51.1 \\
\hline 5 & Debre Zeit native hay & calf & $75-144$ & 0.326 & 0.334 & 0.340 & 0.019 & 0.910 & 65.6 & 0.67 & 0.49 & 72.1 & 57.0 \\
\hline 5 & Debre Zeit native hay & oxen & 217-330 & 0.326 & 0.334 & 0.340 & 0.019 & 0.910 & 65.6 & 0.67 & 0.51 & 77.4 & 63.9 \\
\hline 5 & Napier grass 2 & calf & $55-142$ & 0.373 & 0.397 & 0.230 & 0.021 & 0.910 & 43.1 & 0.50 & 0.57 & 96.5 & 61.9 \\
\hline 5 & Napier grass 2 & oxen & $236-341$ & 0.373 & 0.397 & 0.230 & 0.021 & 0.910 & 43.1 & 0.50 & 0.61 & 94.5 & 74.4 \\
\hline 5 & Oat hay & calf & $67-141$ & 0.327 & 0.413 & 0.260 & 0.017 & 0.910 & 36.9 & 0.67 & 0.52 & 90.4 & 58.3 \\
\hline 5 & Oat hay & oxen & $237-373$ & 0.327 & 0.413 & 0.260 & 0.017 & 0.910 & 36.9 & 0.67 & 0.54 & 69.4 & 71.3 \\
\hline 5 & Pea straw & calf & $46-145$ & 0.223 & 0.203 & 0.574 & 0.029 & 0.910 & 56.3 & 0.37 & 0.34 & 71.6 & 46.0 \\
\hline 5 & Sorghum straw (bird resistant) & calf & $70-133$ & 0.315 & 0.444 & 0.241 & 0.013 & 0.877 & 48.8 & 0.47 & 0.49 & 61.5 & 57.1 \\
\hline 5 & Sorghum straw (bird resistant) & oxen & 213-336 & 0.315 & 0.444 & 0.241 & 0.013 & 0.877 & 48.8 & 0.47 & 0.52 & 72.3 & 64.6 \\
\hline 5 & Sorghum straw (non-bird resistant) & calf & $64-137$ & 0.293 & 0.473 & 0.234 & 0.015 & 0.882 & 50.0 & 0.43 & 0.50 & 73.3 & 56.8 \\
\hline 5 & Sorghum straw (non-bird resistant) & oxen & 216-305 & 0.293 & 0.473 & 0.234 & 0.015 & 0.882 & 50.0 & 0.43 & 0.53 & 53.9 & 65.5 \\
\hline 5 & Sululta native hay & calf & $68-144$ & 0.345 & 0.405 & 0.250 & 0.024 & 0.892 & 63.8 & 0.58 & 0.57 & 79.5 & 62.4 \\
\hline 5 & Sululta native hay & oxen & $205-320$ & 0.345 & 0.405 & 0.250 & 0.024 & 0.892 & 63.8 & 0.58 & 0.59 & 60.0 & 71.5 \\
\hline 5 & Teff straw & oxen & 214-283 & 0.267 & 0.539 & 0.194 & 0.014 & 0.904 & 33.8 & 0.46 & 0.52 & 68.9 & 64.7 \\
\hline 6 & Oat/vetch intercropped roughage & calf & 135-195 & 0.342 & 0.401 & 0.257 & 0.022 & 0.904 & 64.0 & 0.63 & 0.56 & 97.0 & 66.4 \\
\hline 6 & Oat/vetch intercropped roughage & oxen & 208-249 & 0.342 & 0.401 & 0.257 & 0.022 & 0.901 & 64.0 & 0.63 & 0.58 & 95.0 & 70.0 \\
\hline 6 & Oat/vetch intercropped roughage 2 & calf & 105-196 & 0.342 & 0.364 & 0.294 & 0.024 & 0.901 & 64.0 & 0.63 & 0.55 & 97.2 & 63.5 \\
\hline 6 & Oat/vetch intercropped roughage 2 & oxen & $206-226$ & 0.342 & 0.364 & 0.294 & 0.024 & 0.901 & 64.0 & 0.63 & 0.56 & 83.2 & 68.8 \\
\hline 6 & Teff straw & calf & $94-200$ & 0.267 & 0.447 & 0.286 & 0.021 & 0.901 & 41.0 & 0.47 & 0.51 & 100.2 & 58.7 \\
\hline 6 & Teff straw & oxen & $204-227$ & 0.267 & 0.447 & 0.286 & 0.021 & 0.914 & 41.0 & 0.47 & 0.52 & 66.7 & 64.3 \\
\hline 7 & Sorghum NBR & sheep & 16.2 & 0.269 & 0.388 & 0.343 & 0.028 & 0.884 & 60.0 & 0.43 & 0.45 & 66.1 & 48.3 \\
\hline 7 & Sorghum BR & sheep & 16.2 & 0.283 & 0.380 & 0.337 & 0.021 & 0.878 & 40.6 & 0.47 & 0.43 & 56.3 & 47.6 \\
\hline
\end{tabular}

\# 5 = Nsahlai et al., 1996b; 6 = Umunna et al., 1995; 7 = Nsahlai et al., 1998a 
$A$

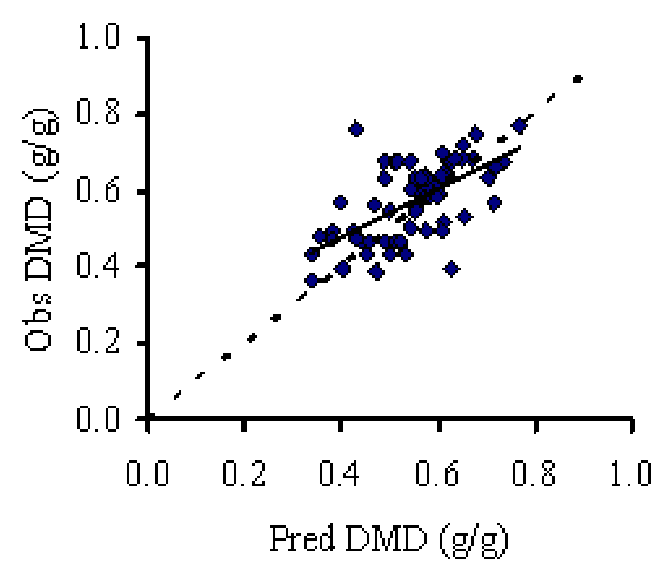

C

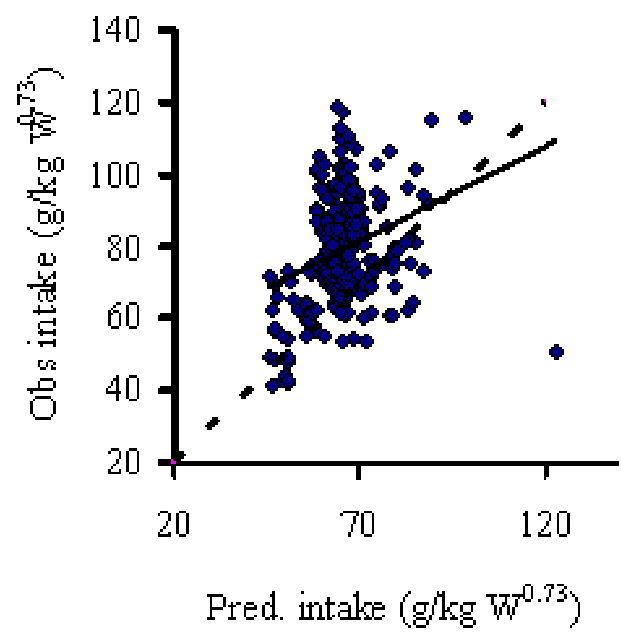

B

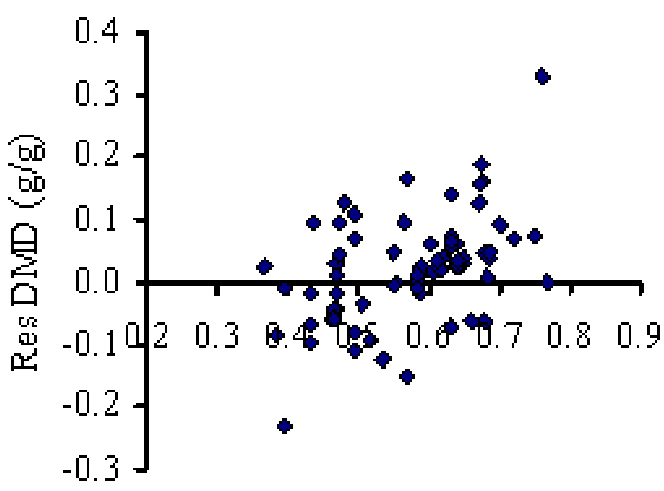

Obs DMD $(g / g)$

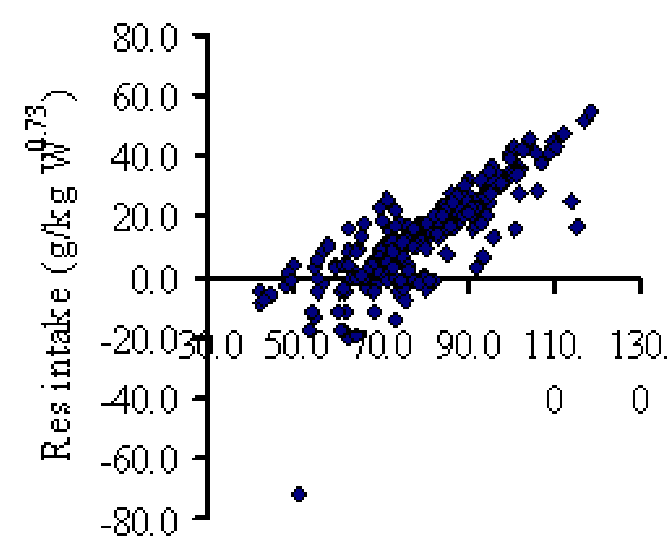

Obs intake $\left(g / \mathrm{kg} \mathrm{w}^{0.73}\right)$

Figure 2 The relationship between: (A) the observed (Obs) and the predicted (Pred) dry matter digestibility (DMD), (B) the observed and the residual DMD, (C) the observed and the predicted intakes and (D) the observed and the residual intakes using all data points. The broken lines in A and $\mathrm{C}$ are lines of perfect agreement between the observed and the predicted values.

\section{Discussion}

A comparison was made between the coefficients of determination $\left(\mathrm{R}^{2}\right)$ obtained from the intake and digestibility values from the simulation study and from the empirical studies (Table 3). Table 3 reveals that the $\mathrm{R}^{2}$ values were generally higher in the empirical studies than in the simulation study. The 
best $\mathrm{R}^{2}$ for the intake relationship were 0.50 for the study by Nsahlai et al. (1996), 0.45 for the study by Shem et al. (1995) and 0.39 for the study by Kibon \& Ørskov (1993). The digestibility relationships of the studies by Umunna et al. (1995), Shem et al. (1995), and Kibon \& Ørskov (1993) accounted for 85\%, $93 \%$ and $86 \%$ of the variation, respectively.

Table 3 The coefficient of determination $\left(\mathrm{R}^{2}\right)$ and residual standard deviations of relationships between observed and predicted intake and digestibility

\begin{tabular}{|c|c|c|c|c|c|c|c|c|}
\hline \multirow[b]{2}{*}{ Source $e^{\#}$} & \multicolumn{4}{|c|}{ Intake } & \multicolumn{4}{|c|}{ Digestibility } \\
\hline & $\mathrm{n}$ & $\begin{array}{c}\text { Empirical } \\
\text { study }\end{array}$ & $\begin{array}{c}\text { Simulation } \\
\text { study }\end{array}$ & $\begin{array}{c}\text { Simulation } \\
\text { RMSE }\end{array}$ & $\mathrm{n}$ & $\begin{array}{c}\text { Empirical } \\
\text { study }\end{array}$ & $\begin{array}{c}\text { Simulation } \\
\text { study }\end{array}$ & $\begin{array}{c}\text { Simulation } \\
\text { RMSE }\end{array}$ \\
\hline 1 & 14 & 0.41 & 0.16 & 10.11 & 14 & 0.19 & 0.37 & 0.085 \\
\hline 1 & 8 & 0.98 & 0.50 & 6.52 & 8 & 0.81 & 0.12 & 0.058 \\
\hline 2 & 2 & ND & ND & ND & 2 & ND & ND & ND \\
\hline 3 & 18 & 0.81 & 0.45 & 9.01 & 18 & 0.90 & 0.93 & 0.017 \\
\hline 4 & 5 & 0.99 & 0.39 & 4.13 & 5 & 0.98 & 0.86 & 0.022 \\
\hline 5 & 93 & 0.79 & 0.22 & 11.67 & 15 & ND & 0.01 & 0.120 \\
\hline 6 & 93 & ND & 0.02 & 11.63 & 6 & ND & 0.85 & 0.036 \\
\hline 7 & 2 & ND & ND & ND & 2 & ND & ND & ND \\
\hline
\end{tabular}

\# 1 = Nsahlai et al., 1996a; 2 = Mpairewe, 1998; 3 = Shem et al., 1995; 4 = Kibon \& Ørskov, 1993; 5 = Nsahlai et al., 1996b; 6 = Umunna et al., 1995; 7 = Nsahlai et al., 1998a. $\mathrm{n}$ is the number of observations, RMSE is the root mean square error, ND means not determined

These $\mathrm{R}^{2}$ values for digestibility relationships obtained from the predicted values from the simulation and the observed values from the field experiments were high and (or) compared reasonably well with $\mathrm{R}^{2}$ values reported in the empirical studies by Shem et al. (1995), Kibon \& Ørskov (1993) and Umunna et al. (1995) but were either modest or poor for the rest. The overall trend between the observed and the predicted digestibility is positive, though accounting for just $36-52 \%$ of the total variation, which does not compare favourably with an $\mathrm{R}^{2}$ of $70 \%$ previously obtained with the application of the simulation model to temperate roughages (Illius \& Gordon, 1991). Besides that the current simulation study covered a wider range of roughage diets than the study of Illius \& Gordon (1991), the poorer performance of the model in this wider range of roughage diets may be due to the following reasons. Firstly, the fractional outflow rate of fine particles $\left(\mathrm{k}_{\mathrm{p}}\right)$ is estimated by allometry as the inverse function of live weight, which implies that $k_{p}$ would be higher for small than for large ruminants. This agrees with the observation that under similar dietary conditions, digestibility in sheep is lower than in cattle (Siebert \& Kennedy, 1972; Bird, 1974; Ammaning-Kwarteng et al., 1986) which partly is the result of a shorter retention time in sheep than cattle. Given that the allometric coefficient was obtained using ruminants ranging from $3.8 \mathrm{~kg}$ to $1000 \mathrm{~kg}$ (Illius \& Gordon, 1991) which were foraging in a natural ecosystem, and that the selection for high quality feed items is more intense for small than for large ruminants in exceptionally poor environments (Gordon \& Illius, 1996), it is conceivable that the magnitude of the scaling factor is partly linked to diet quality. It has been demonstrated in a variety of empirical studies that $\mathrm{k}_{\mathrm{p}}$ is a function of diet quality (Campling et al., 1962; Freer et al., 1962; Pearson \& Archibald, 1990; Vega \& Poppi, 1997). Perturbations arising as a result of applying allometry without correcting for 
dietary quality when estimating $\mathrm{k}_{\mathrm{p}}$ values could have unpredictable consequences on the nature of the relationship between the predicted and observed digestibility. This is why it would perhaps be necessary to determine the modulating impact of diet quality on the magnitude of the allometric coefficient. Furthermore, the severity of over-prediction by the simulation model mostly occurred when leguminous forages were fed to ruminants. This may be linked to the fact that whilst the rumen environment might not have been limiting during degradation studies, changes in ruminal $\mathrm{pH}$ and high $\mathrm{k}_{\mathrm{p}}$ during the in vivo phase and the effect of anti-nutritional factors could have negatively impacted on the digestibility of these forages when used as the sole feed (Nsahlai \& Umunna, 1996).

Secondly, based on the prescription of the in sacco method, degradation properties of feeds are generally determined in the rumen of animals whose feed has been adequately supplemented with $\mathrm{N}$, which is the first nutrient that limits the intensity of ruminal microbial fermentative activity for low quality roughage diets. Supplementation of N-deficient roughage with urea has been shown to increase digestibility of roughage diets by 4 - 40\% depending on the quality of the basal roughage (Nsahlai, 1991) in the face of increased intake, which can partly be explained by an increased rate of digestion. Indeed, it has been demonstrated that supplementation of $\mathrm{N}$-deficient roughage with forage legumes can result in an almost two-fold increase in the rate of degradation (Nsahlai et al., 1998a) and of passage (Abule et al., 1995; Bonsi et al., 1995). Since the change in the rate of digestion of N-deficient roughage following supplementation with $\mathrm{N}$ is inversely related to the intrinsic quality of the roughage (Nsahlai 1991; Nsahlai et al., 1998a), it is likely that our use of the rate of digestion $\left(\mathrm{k}_{\mathrm{dig}}\right)$ derived under dietary conditions that are different to those imposed during the in vivo digestion studies would negatively impact on the performance of the simulation model. Moreover, the current implementation of the nylon bag technique does hardly account for the selective feeding of stall fed animals, which could result in underestimation of the $\mathrm{k}_{\mathrm{dig}}$ of ingesta since it has been shown that sheep select a diet which is 2 - 5\% more degradable than the offered feed (Nsahlai et al., 1998b). The degree to which the above two opposing effects can counterbalance each other is yet to be determined. Interestingly, the residual plot (Figure 1B) further supports that the poor prediction of digestibility may be unrelated to structural deficiencies of the model, and thus is most likely a consequence of the limitation of data used to determine the parameters $\mathrm{k}_{\mathrm{dig}}$ and $\mathrm{k}_{\mathrm{p}}$. For instance, the best performance of the model was observed in studies (Kibon \& Ørskov, 1993; Shem et al., 1995; Nsahlai et al., 1996a) where diets used during the degradability and intake phases were non-limiting in protein and readily fermentable fibre. It is, thus, recommended that similar dietary conditions should be used when deriving input variables and during the feeding study.

In relation to intake prediction, a good proportion of the variation was accounted for in studies where feeds comprised forage legumes or browse (Kibon \& Ørskov, 1993; Nsahlai et al., 1996) or when diets were supplemented with protein during both phases of the study (Shem et al., 1995). Considering the entire data set, it is perhaps noteworthy that the relationship between the observed and the predicted intake could account for barely $15 \%$ and $20 \%$ of the variation before and after eliminating $5 \%$ of the outlying observations, respectively. This again is a poorer performance than has been observed by Illius \& Gordon (1991), perhaps because whilst they used a fairly restricted dataset, this study has 10 -fold the number of observations used by Illius \& Gordon (1991). A closer analysis of the intake and the residual plots (Figure 2C \& D) suggested that intake was poorly predicted for roughages that elicited high intake such as crop residues comprised of a mixture of legume and cereal straws. The first most influential parameter affecting intake is the rumen digesta load (Poppi et al., 1981b; Illius \& Gordon, 1991; Sauvant et al., 1996) which then empties at a rate determined by $\mathrm{k}_{\mathrm{p}}$ and $\mathrm{k}_{\mathrm{dig}}$. For a given rumen load and feed quality, the rate of feed intake is expected to increase in direct proportion with the $\mathrm{k}_{\mathrm{p}}$ value. Furthermore, $\mathrm{k}_{\mathrm{p}}$ is also influence by the fragility of the feed which increases with age and thus with the cell wall content and should differ between cereal straws and legume (Allen, 1996). However, based on the manner the 
model is calibrated, if feed quality becomes variable, the rate of change of feed intake in response to changes in feed quality will be dampened by the lack of change in $\mathrm{k}_{\mathrm{p}}$ at a given animal size. Consequently, the insensitivity of $k_{p}$ to feed quality is contrary to expectation (McCollum \& Galyean 1985) but could partly explain why the model systematically underestimated the intake of roughage diets that elicited high intakes.

There is compelling evidence suggesting that the rumen digesta load can be influenced by diet quality (Campling et al., 1961; 1962; Egan, 1970) and by the degree of maturity (Butterfield, 1988) or the animal's propensity to utilize energy (Egan, 1965; Hovel et al., 1983; Weston et al., 1989; Allen, 1996). However, there is also evidence indicating that the effect of diet quality is small (Vega \& Poppi, 1997). Consequently, the response of an animal to changes in diet quality may be linked to its physiological state. Indeed, Weston (1989) demonstrated higher digesta load in lambs than in mature sheep and that this difference increased from $22 \%$ to $40 \%$ for diets with $1.38 \% \mathrm{~N}$ and $2.91 \% \mathrm{~N}$, respectively. The allometric functions estimate rumen digesta load and $\mathrm{k}_{\mathrm{p}}$ based on live weight alone, when perhaps the allometric coefficient should be modulated by both of these attributes. It is generally accepted that the rate of disappearance of digesta from the rumen is positively associated with feed quality and that small ruminants are more selective of nutritious herbage than large ruminants. Thus, these estimates of the allometric coefficients should, at best, be used with justifiable reservation. Consequently, in order to improve on the accuracy of this model, generalized estimates of the rumen digesta load and other relevant scaling parameters should be done following procedures that simultaneously account for the effect of both the feed quality and animal's productive state.

Implicit in the above discussion is the hypothesis that better predictions of intake can be achieved by adjusting for the effect of diet quality and stage of production. To test this hypothesis it would be necessary to determine the $\mathrm{k}_{\mathrm{p}}$ and rumen DM load. It has been reported that the rate of passage of digesta through the rumen is a function of diet density (Faichney, 1986; Lechner-Doll et al., 1991) and that density is a function of the rate of fermentation of fibre and the potentially fermentable fibre fraction (Jung \& Allen, 1995). An attempt was thus made to estimate $\mathrm{k}_{\mathrm{p}}$ using feed attributes (NDF g/g, $\mathrm{k}_{\mathrm{dig}} / \mathrm{h}$ ) and live weight (kg) based on data from studies reported by Nsahlai (1991), Abule et al. (1995), Bonsi (1995), Ndlovu \& Hove (1995), Vega \& Poppi (1997), Mpairwe (1998) and Yue-ming et al. (2005). The best relationship for predicting $\mathrm{k}_{\mathrm{p}}\left(\mathrm{k}_{3}\right)$ rejected the live weight and took the form: $\mathrm{k}_{\mathrm{p}}(/ \mathrm{h})=0.0907 \mathrm{x} \mathrm{NDF}{ }^{-0.373} \mathrm{x}$ $\mathrm{k}_{\mathrm{dig}}{ }^{0.40}(\mathrm{n}=72$; RMSE $=0.233$ ) but could explain $37 \%$ of the variation. In order to determine rumen DM load, data reported by others (Poppi et al., 1980; Weston, 1989; Vega \& Poppi, 1997) were used to describe rumen DM load (RL) as a function of live weight (W) expressed as a proportion of the mature

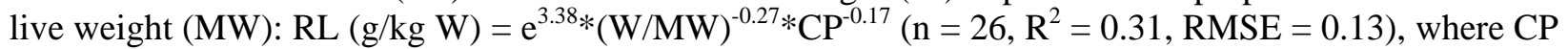
$(\mathrm{g} / \mathrm{kg})$ is the crude protein.

The above functions were intended to implicitly account for the growth state and diet quality and thus were used to compute the $\mathrm{k}_{\mathrm{p}}$ and the rumen DM load that were used in re-running the model. The rerun of the model with these two parameters indicated the relationship between the observed and the predicted account for $32 \%$ and $49 \%$ of the variation of the digestibility and intake, respectively. Further analysis of individual studies (see Table 4) supports our hypothesis, and shows improvements in $\mathrm{R}^{2}$ values for intake relationships for all but two sources of data. On the contrary, $\mathrm{R}^{2}$ values for digestibility relationships decreased for all but one study, perhaps for the same reasons discussed above on how $\mathrm{k}_{\mathrm{dig}}$ was determined. It is thus worthwhile to design appropriate studies for deriving generalized estimates of these parameters. 
Table 4 The coefficient of determination $\left(\mathrm{R}^{2}\right)$ of relationships between observed and predicted intake and digestibility after adjusting $\mathrm{kp}$ and rumen DM load

\begin{tabular}{ccccccc}
\hline & \multicolumn{2}{c}{ Intake } & \multicolumn{3}{c}{ Digestibility } \\
\hline Source $^{\#}$ & $\mathrm{n}$ & $\begin{array}{c}\text { Empirical } \\
\text { study }\end{array}$ & $\begin{array}{l}\text { Simulation } \\
\text { study: new } \\
\text { parameters }\end{array}$ & $\mathrm{n}$ & $\begin{array}{c}\text { Simulation } \\
\text { Empirical } \\
\text { study }\end{array}$ & $\begin{array}{c}\text { study: new } \\
\text { parameters }\end{array}$ \\
\hline 1 & 14 & 0.16 & 0.00 & 14 & 0.37 & 0.31 \\
1 & 8 & 0.50 & 0.03 & 8 & 0.12 & 0.10 \\
2 & 2 & ND & ND & 2 & ND & ND \\
3 & 18 & 0.45 & 0.66 & 18 & 0.93 & 0.85 \\
4 & 5 & 0.39 & 0.89 & 5 & 0.86 & 0.78 \\
5 & 93 & 0.22 & 0.41 & 15 & 0.01 & 0.11 \\
6 & 93 & 0.02 & 0.02 & 6 & 0.85 & 0.90 \\
7 & 2 & ND & ND & 2 & ND & ND
\end{tabular}

\# 1 = Nsahlai et al., 1996a; 2 = Mpairewe, 1998; 3 = Shem et al., 1995; 4 = Kibon \& Orskov, 1993; 5 = Nsahlai et al., 1996b; 6 = Umunna et al., 1995; 7 = Nsahlai et al., 1998a. ND means, not determined

Lastly, data presented in this study was neither collected in a single location nor obtained in one season, when it is known that changes in ambient conditions (temperature, humidity, storm, etc) can profoundly affect intake. In addition, given the diverse sources of data it is possible previous nutrition might have influenced rumen DM load (Ryan, 1990) and intake. Consequently, while this model is being used in ecological systems where ruminants are allowed free access to growing herbage, it will require proper fine-tuning before it can lend its usefulness in the livestock production systems (such as in stall feeding systems) in which the selection intensity for nutritious components of food can at best only be limited. Since stall feeding enables rigorous testing in order to lend confidence to the model's predictions of intake and digestibility by animals on tropical pastures and range, such a fine-tuning process would increase its value as a component of the ecosystem models. For range and pasture studies, in sacco estimation of $\mathrm{k}_{\mathrm{dig}}$ for oesophageal fistula samples should be carried out in animals grazing the same range as the animals from which the samples are taken.

\section{References}

Abule, E., Umunna, N.N., Nsahlai, I.V., Osuji, P.O. \& Yami, A., 1995. The effect of supplementing teff (Eragrotis tef) straw diet with graded levels of cowpea (Vigna unguiculata) and lablab (Lablab purpureus) on degradation, rumen particulate passage rate and intake by crossbred calves. Livest. Prod. Sci. 44, 221-228.

Agricultural Research Council, 1980. The Nutrient Requirements of Ruminant Livestock. Commonwealth Agricultural Bureaux. Slough, UK.

Allen, M.S., 1996. Physical constraints on voluntary intake of forages by ruminants. J. Anim. Sci. 70, 3063-3075.

Amaning-Kwarteng, K., Kellaway, R.C., Spragg, J.C. \& Kirby, A.C., 1986. Comparative intake and digestibility by sheep and cattle of $\mathrm{NaOH}$-treated straw. Proc. Aust. Soc. Anim. Prod. 16, 131-134.

Bird, P.R., 1974. Sulphur metabolism and excretion studies in ruminants. 13. Intake and utilization of wheat straw by sheep and cattle. Aust. J. Agric. Res. 25, 631-642. 
Blummel, M. \& Ørskov. E.R., 1993. Comparison of in vitro gas production and nylon bag degradability of roughages in predicting intake in cattle. Anim. Feed Sci. Technol. 40, 109-119.

Bonsi, M.L.K, Osuji, P.O. \& Tuah, A.K., 1995. The effect of supplementing teff straw with different levels of leaucaena or sesbania leaves on the degradability of teff straw, sesbania, leacaena, tagasaste and vernonia and on certain rumen and blood metabolites in Ethiopian Menz sheep. Anim. Feed Sci. Technol. 52, 101-129.

Bonsi, M.L.K., 1995. The role of fodder trees in the utilization of roughage by sheep. $\mathrm{PhD}$ thesis, University of Science and Technology (UST), Ghana.

Butterfield, R.M., 1988. New Concepts of Sheep Growth. Department of Veterinary Anatomy, University of Sydney and the Australian Feeding Standards for Ruminants 1990. CSIRO. 168 pp.

Campling, R.C., Freer, M. \& Balch, C.C., 1961. Factors affecting voluntary intake of food by cows. 2. The relationship between the voluntary intake of roughages, the amount of digesta in the recticulo-rumen and the rate of disappearance of digesta from the alimentary tract. Br. J. Nutr. 11, 531-540.

Campling, R.C., Freer, M. \& Balch, C.C., 1962. Factors affecting voluntary intake in cows. 3. The effect of urea on the voluntary intake of oat straw. Br. J. Nutr. 16, 115-124.

Egan, A.R., 1965. Nutritional status and the intake regulation in sheep. 3. The relationship between improvement of nitrogen status and increased voluntary intake of low nitrogen roughages by sheep. Aust. J. Agric. Res. 16, 463-472.

Egan, A.R., 1970. The nutritional status and intake regulation in sheep. 6. Evidence for variation in setting of an intake regulatory mechanism relating to the digesta content in the reticulorumen. Aust. J. Agric. Res. 21, 35-746.

Egan, A.R., 1977. Nutritional status and the intake in sheep. 8. Relationship between the voluntary intake of herbage by sheep and the protein energy ratio in the digestion products. Aust. J. Agric. Res. 28, 907915.

Faichney, G.A., 1986. The kinetics of particulate matter in the rumen. In: Control of Digestion and Metabolism in Ruminants. Eds. Milligan, L.P., Grovum, W.L. \& Dobson, A., Prentice-Hall, Englewood Cliffs, N.J., USA. p.173.

Freer, M., Campling, R.C. \& Balch, C.C., 1962. Factors affecting voluntary intake of food by cows. 4. The behaviour and recticular motility of cows receiving diets of hay, oat straw and oat straw with urea. Br. J. Nutr. 16, 279-295.

Gordon, I.J. \& Illius, A.W., 1996. The nutritional ecology of African ruminants: a reinterpretation. J. Anim. Ecol. 65, 18-28.

Hartnell, G.F. \& Satter, L.D., 1979. Determination of rumen fill, retention time and ruminal turnover rates of ingesta at different stages of lactation in dairy cows. J. Diary Sci. 48, 381-392.

Hovel, F.D., Ørskov, E.R., Grubb, D.A. \& McLeod, N.A., 1983. Basal urinary nitrogen excretion and growth responses to supplemental protein by lambs close to energy equilibrium. Br. J. Nutr. 50, 173-187.

Illius, A.W. \& Gordon, I.J., 1991. Prediction of intake and digestion in ruminants by a model of rumen kinetics integrating animal size and plant characteristics. J. Agric. Sci., Camb. 116, 145-157.

Jung, H.G., \& Allen, M.S., 1995. Characteristics of plant cell walls affecting intake and digestibility of forages by ruminants. J. Anim. Sci. 73, 2774.

Kibon, A. \& Ørskov, E.R., 1993. The use of degradation characteristics of browse plants to predict intake and digestibility by goats. Anim. Prod. 57, 247-251.

Lechner-Doll, M., Kaske, M. \& Von Englehardt, W., 1991. Factors affecting the mean retention time of particles in the forestomachs of ruminants and camelids. In: Physiological Aspects of Digestion and Metabolism in Ruminants. Eds. Tsuda, T., Sasaki, Y. \& Kawashima, R., Academic Press, New York. 
Lindsay, J.A., Mason, G.W.J. \& Toleman, M.A., 1982. Supplementation of pregnant cows with protected proteins when fed tropical forage diets. Proc. Aust. Soc. Anim. Prod. 14, 67-68.

McCollum, F.T. \& Galyean, M.L., 1985. Influence of cottonseed meal supplementation on voluntary intake, rumen fermentation and rate of passage of prairie hay in beef steers. J. Anim. Sci. 60, 570-577.

Mehrez, N.P. \& Ørskov, E.R., 1977. A study of the artificial fibre bag technique for determining the digestibility of feeds in the rumen. J. Agric. Sci., Camb. 88, 645-650.

Mpairwe, D.R., 1998. Integration of forage legumes with cereal crops for improved grain yield, forage production and utilisation for smallholder dairy production systems $\mathrm{PhD}$ thesis, Makerere University, Uganda. 241 pp.

Ndlovu, L.R. \& Hove, L., 1995. Intake, digestion and rumen parameters of goats fed mature veld hay ground with deep litter poultry manure and supplemented with graded levels of poorly managed groundnut hay. Livestock Res. Rural Dev. 6(3):

http://www.fao.org/ag/aGa/AGAP/FRG/FEEDback/lrrd/lrrd6/3/8.htm

Nsahlai, I.V., 1991. The effect of quantity and quality of dietary nitrogen on the utilization of roughage diets by steers. Ph.D. thesis, University of Reading, UK.

Nsahlai, I.V. \& Umunna, N.N., 1996. Comparison between reconstituted sheep faeces and rumen fluid inocula and between in vitro and in sacco digestibility methods as predictors of intake and in vivo digestibility. J. Agric. Sci., Camb. 126, 235-248.

Nsahlai, I.V., Bonsi, M.L.K., Umunna, N.N., Sileshi, Z. \& Bediye, S., 1998a. Feed utilization strategies for improved ruminant production in the arid region. Annals of Arid Zone 37 (3), 283-310.

Nsahlai, I.V., Bryant, M.J. \& Umunna, N.N., 1998b. Utilisation of barley straw by steers: Effect of quantity and source of Nitrogen on the degradation of straw fractions, particle outflow rate and intake. J. Appl. Anim. Res. 14, 33-50.

Nsahlai, I.V., Osuji, P.O. \& Umunna, N.N., 2000. Effect of form and quality of feed on the concentrations of purine derivatives in urinary spot samples, daily microbial $\mathrm{N}$ supply and predictability of intake. Anim. Feed Sci. Technol. 25, 223-238.

Nsahlai, I.V., Umunna, N.N. \& Osuji, P.O., 1996b. An empirical mathematical model for predicting voluntary intake of forage legume-supplemented roughages by cattle. All Africa Conference on Animal Agriculture, Pretoria, South Africa, 01-04 April, 1996.

Nsahlai, I.V., Umunna, N.N. \& Osuji, P.O., 1998c. Complementarity of bird-resistant and non-birdresistant varieties of sorghum stover with cottonseed cake and noug (Guizotia abyssinica) cake when fed to sheep. J. Agric. Sci., Camb. 130, 229-239.

Ørskov, E.R., Reid, G.W., \& Kay, M., 1988. Prediction of intake of cattle from degradation characteristics of roughages. Anim. Prod. 46, 29-35.

Ortigues, I., Smith, T., Oldham, J.D., McAllan, A.B. \& Siviter, J.W., 1989. Nutrient supply and growth of cattle offered straw-based diets. Br. J. Nutr. 62, 601-619.

Pearson, R.A. \& Archibald, R.F., 1990. Effect of ambient temperature and urea supplementation on the intake and digestion of alkali-treated straw by Brahman cattle and swamp buffaloes. J. Agric. Sci., Camb. 114, 177-186.

Poppi, D.P., Minson, D.J. \& Ternouth, J.H., 1980. Studies of cattle and sheep eating leaf and stem fractions of grasses. I. The voluntary intake, digestibility and retention time in the reticulo-rumen. Aust. J. Agric. Res. 32, 99-108.

Poppi, D.P., Minson, D.J. \& Ternouth, J.H., 1981a. Studies of cattle and sheep eating leaf and stem fractions of grasses. II. Factors controlling the retention of feed in the reticulo-rumen. Aust. J. Agric. Res. 32, 109-121. 
Poppi, D.P., Minson, D.J. \& Ternouth, J.H., 1981b. Studies of cattle and sheep eating leaf and stem fractions of grasses. III. The retention time in the rumen of large feed particles. Aust. J. Agric. Res. 32, 123-127.

Robellin, J. \& Geay, Y. 1984. Body composition of cattle as affected by physiological status, breed, sex and diet. In: Herbivore Nutrition in the Subtropics and Tropics. Eds. Gilchrist, F.M.C. \& Mackie, R.I., Science Press, South Africa. pp. 525-548.

Ryan, W.J., 1990. Compensatory growth in cattle and sheep. Nutr. Abstr. Rev. (Series B), 60 (9), 653-664.

SAS, 2002/2003. Statistical Analysis Systems user's guide (Release 9.1.3). SAS Institute Inc., Cary N.C., USA.

Sauvant, D., Baumont, R. \& Faverdin, P., 1996. Development of a mechanistic model of intake and chewing activity of sheep. J. Anim. Sci. 94, 2785-2802.

Shem, M.N, Ørskov, E.R. \& Kimambo, A.E., 1995. Prediction of voluntary dry matter intake, digestible dry-matter intake and growth of cattle from the degradation characteristics of tropical foods. Anim. Sci. 60, 65-74.

Siebert, E.D. \& Kennedy, P.M., 1972. The utilization of spear grass (Heteropogon contortus). 1. Factors limiting intake and utilization by sheep and cattle. Aust. J. Agric. Res. 23, 35-44.

Umunna, N.N., Osuji, P.O. \& Nsahlai, I.V., 1997. Strategic supplementation of crossbred steers fed forages from cereal-legume cropping system with cowpea hay. J. Appl. Anim. Res. 11, 169-182.

Van Soest, P.J., Robertson, J.B. \& Lewis, B.A., 1991. Methods of dietary fiber, neutral detergent fiber and non-starch polysaccharides in relation to animal nutrition. J. Dairy Sci. 74, 3582-3597.

Vega, D.A. \& Poppi, D.P., 1997. Extent of digestion and rumen condition as factors affecting passage of liquid and digesta particles in sheep. J. Agric. Sci., Camb. 128, 207-215.

Weston, R.H., 1988. Factors limiting the intake of feed by sheep. 13. Voluntary roughage consumption in late pregnancy and early lactation in relation to protein nutrition. Aust. J. Agric. Res. 39, 679-689.

Weston, R.H., Lindsay, J.R., Peter, D.W. \& Buscall, D.J., 1989. Factors limiting the intake of feed by sheep. 14. Comparison of voluntary feed consumption and various transactions in the alimentary tract between lambs and sheep fed roughage diets. Aust. J. Agric. Res. 40, 625-642.

Yue-ming, W.U., Wei-lian, H.U. \& Liu Jian-xin, 2005. Effect of supplementary urea-minerals lick block on the kientics of fibre digestion, nutrient digestibility and nitrogen utilization of low quality roughages. J. Zhejiang Univ. Sci. 6B, 793-797. 